\title{
Yeni Koronavirüs (SARS-CoV-2) Kaynaklı Pandemi: Gelișmeler ve Güncel Durum
}

\section{Novel Coronavirus (SARS-CoV-2) Pandemic: Overview and Current Status}

\author{
Șehnaz $A$ PPl(iD), Serhat ÜNAL $^{1}$ (ID)
}

${ }^{1}$ Hacettepe Üniversitesi Tıp Fakültesi, İnfeksiyon Hastalıkları ve Klinik Mikrobiyoloji Anabilim Dalı, Ankara, Türkiye

Makale atıf: Alp Ş, Ünal S. Yeni koronavirüs (SARS-CoV-2) kaynaklı pandemi: Gelişmeler ve güncel durum. FLORA 2020;25(2):111-20.

\section{ÖZ}

Illk olarak 2019 yılı Aralık ayında, Çin'in Wuhan şehrinde nedeni belirlenemeyen pnömoni olgularııı bildirilmesi üzerine yapılan incelemeler sonucunda etkenin yeni bir koronavirüs olduğu anlaşılmış, etken SARS-CoV-2 (severe acute respiratory syndrome coronavirus-2) olarak tanımlanmış, hastalık ise COVID-19 (coronavirus disease-2019) olarak adlandırılmıştır. Hastalık başlangıçta zoonotik kabul edilmiş olmakla birlikte, insandan insana bulaş varlığı da gösterilmiş ve temel bulaş yolu haline gelmiş, kısa süre içinde olgu sayılarında belirgin artış ortaya çıkmış ve hastalık dünya çapında yayılım göstermiştir. Dünya Sağlık Örgütü 11 Mart 2020 tarihinde COVID-19'u küresel bir pandemi olarak ilan etmiştir. COVID-19 tanısı alan kişi sayısının 6 Mayıs 2020 tarihli verilere dayanılarak 3.588 .773 olduğu, 215 farklı ülke ve bölgeden olgu bildirimleri yapıldığı, hastalık nedeniyle 247.503 kişinin yaşamını yitirdiği rapor edilmiştir. Ülkemizde ise ilk olgu 10 Mart 2020 tarihinde saptanmış, hastalığa bağı ilk ölüm 17 Mart 2020 tarihinde rapor edilmiş, 6 Mayıs 2020 tarihli verilere göre ülkemizde saptanmış olan toplam olgu sayısı 131.744, hastalı̆ga bağlı ölüm sayısı 3584 olarak bildirilmiştir. SARS-CoV2'nin biyolojisi, epidemiyolojisi ve oluşturduğu klinik tablonun özellikleri ile ilgili bilgiler her geçen gün artmaktadır. Viral genomun dizi analizinin yapılmıs olması tanısal testlerin geliştirilmesine, tedavi ve aşı geliştirme alanındaki çalışmaların başlamasına olanak tanımıştır. Bu derleme yazıda, SARS-CoV-2'nin neden olduğu hastalık tablosu ve epidemiyolojisi, tanı, tedavi ve hastalıktan korunma önlemleri konusundaki gelişmeler tartışılmıştır.

Anahtar Kelimeler: SARS-CoV-2; COVID-19; Yeni koronavirüs

\section{ABSTRACT \\ Novel Coronavirus (SARS-CoV-2) Pandemic: Overview and Current Status}

\author{
Șehnaz ALPl, Serhat ÜNAL'
}

${ }^{1}$ Department of Infectious Diseases and Clinical Microbiology, Faculty of Medicine, University of Hacettepe, Ankara, Turkey

In the end of December 2019, a novel coronavirus was identified as the cause of pneumonia cases in Wuhan, China. The disease was later named as COVID-19 (coronavirus disease 2019) and the causative agent was designated as SARS-CoV-2 (severe acute respiratory syndrome coronavirus 2). Even though the disease was suggested to be of zoonotic origin, human to human spread was also described and became the main mode of transmission. The number of cases significantly increased within a short period of time and the disease spread worldwide. On March 11, 2020, the World Health Organization announced COVID-19 outbreak as a pandemic. As of May 6,

Geliș Tarihi/Received: 08/05/2020 - Kabul Ediliș Tarihi/Accepted: 11/05/2020

${ }^{\circ}$ Telif Haklı 2020 Flora. Makale metnine www.floradergisi.org web adresinden ulașılabilir 
2020, it has been reported that there are 3.588.773 people diagnosed with COVID-19 among 215 countries, territories or areas, and 247.503 people have died from the disease. In our country, the first case was identified on March 10, 2020, and the first death from the disease was reported on March 17, 2020. According to the data announced on May 6, 2020, the total number of cases detected in our country was 131.744, and the number of deaths related to the disease was 3584. The knowledge on the characteristics and epidemiology of SARS-CoV-2 and COVID-19 has been increasing day by day. Sequence analysis of the viral genome enabled the development of diagnostic tests and facilitated the initiation of research on both therapeutic options and vaccine development. In this review article, current information on the biology, epidemiology, clinical features, diagnosis, treatment, and prevention of SARS-CoV-2 and COVID-19 was discussed.

Key Words: Severe acute respiratory syndrome coronavirus 2; SARS-CoV-2; Coronavirus disease-2019; COVID-19; Novel coronavirus

\section{Giriș}

Koronavirüsler, kedi, köpek, yarasa, domuz, kanatllar ve kemirgenlerde bulunabilen, hayvanlardan insanlara bulaşabilen, solunum yolu ve gastrointestinal sistem infeksiyonlarına, daha nadir olarak hepatik, nörolojik ve nefrotik tutulumla seyreden hastallk tablolarına neden olabilen zoonotik viral patojenlerdir. Koronavirüslerin özellikle HCoV-229E, HCoV-NL63, HCoV-OC43 ve HCoV-HKU1 alt tiplerinin insanlarda genellikle hafif seyirli üst solunum yolu infeksiyonlarına, nadir olarak daha ağır seyredebilen alt solunum yolu infeksiyonlarına neden olabildiği bilinmekle birlikte, 2003 ylında ağır akut solunum sendromu [Severe Acute Respiratory Syndrome (SARS)] ve 2012 yilında Orta Doğu solunum sendromu [Middle East Respiratory Syndrome (MERS)] olarak tanımlanmıs oldukça ciddi klinik tablolardan da sorumlu olabildikleri gösterilmiștir ${ }^{[1-5]}$.

Dünya Sağllk Örgütü (DSÖ) Çin Ülke Ofisi'nin 31 Aralı 2019 tarihinde Cin'in Hubei eyaletinde yer alan Wuhan sehrinde mevcut testlerle nedeni belirlenemeyen pnömoni olgularının varlığını bildirmesiyle baslayan inceleme ise 7 Ocak 2020'de etkenin insanlarda infeksiyona neden olan yeni bir koronavirüs olduğunu ortaya koymusturtur ${ }^{[1-6]}$. Etken virüs, DSÖ tarafından 2019-nCoV (2019-novel coronavirus), Uluslararası Virüs Taksonomi Komitesi tarafindan ise SARS-CoV-2 (severe acute respiratory syndrome coronavirus-2) olarak adlandırılmıs, virüsün neden olduğu hastallk ise COVID-19 (coronavirus disease-2019) olarak tanımlanmıștır ${ }^{[1,7]}$.

\section{ETKEN VIRÜS}

Koronavirüsler, Nidovirales sınıfındaki Coronaviridae ailesinin Coronavirinae alt ailesinde yer alan tek zincirli, pozitif polariteli, zarflı RNA virüsleridir. Yüzeylerinde bulunan cubuk seklindeki uzantılar nedeniyle Latince'de "tac" anlamına gelen "corona" kelimesinden yola c1kilarak bu virüsler "coronavirus" olarak isimlendirilmiștir. Coronavirinae, alfa koronavirüsler, beta koronavirüsler, gama koronavirüsler ve delta koronavirüsler olarak dört alt gruba ayrilmaktadır. Daha önce seroloji temelli yaklașım ile yapılan gruplandırma günümüzde filogenetik analiz ile belirlenmektedir ${ }^{[2,4,9]}$. Koronavirüs alt gruplarının doku tropizmi ve konak dağılımları farklıdır. Genellikle, alfa koronavirüsler ve beta koronavirüsler memelileri infekte eder. Delta koronavirüsler ve gama koronavirüsler ise kusları ve balıkları infekte etmektedir ancak bazen memelileri de infekte edebildiği belirtilmektedir ${ }^{[4]}$. Yapılmıs olan dizi analizleri SARS-CoV2'nin koronavirüslere özgü genom yapısında olduğunu, beta koronavirüsler arasında yer aldığını, koronavirüslerin filogenetik ağacına göre de yarasa SARS-benzeri koronavirüsleri olarak tanımlanan bat-SL-CoV ZC45 ve bat-SL-CoV ZXC21 ile yakın ilișkili olduğunu ortaya koymuștur ${ }^{[3,4]}$. Koronavirüslerdeki dört yapısal protein olgun virüs partikülü (virion) olușumunda ve infeksiyonun ortaya cıkmasında görev almaktadır. Bunlar S (Spike) proteini, E (Envelope) proteini, M (Membran) proteini ve $\mathrm{N}$ (Nucleocapsid) proteinidir. S proteini, koronavirüsün yüzeyindeki cıkıntıların (spike) olusumundan, bu cıkıntılar ise virüsün konak hücre reseptörlerine tutunmasından ve hücre içine girisinden sorumludur. Ayrıca, virüsün majör antijenik özelliğini sağlamaktadır. S proteininin insanlarda anjiyotensin dönüștürücü enzim 2 [angiotensin-converting enzyme 2 (ACE2)] reseptörüne yüksek afinite ile bağlandığı ve ACE2 enziminin akciğer dokusunda özellikle tip-II alveoler hücrelerde yük- 
sek oranda eksprese edildiği gösterilmiștir. ACE2 enziminin akciğer dokusu dișında eksprese edildiği bașlica yapiların kalp, böbrek, vasküler endotel ve bağırsak epiteli olduğu belirtilmiștir ${ }^{[4,10,11]}$. Bağırsak lümenindeki yüzeyel epitel hücrelerinde de ACE2 enziminin yuiksek oranda eksprese edilmesi solunum yolu dișinda intestinal sistemin de SARSCoV-2 için bir giriș kapısı olușturabileceğine ve infeksiyonun deniz ürünleri ve canlı hayvan pazarındaki yiyeceklerin sindirim yoluyla alınması ile bașlamıș olabileceğine ilișkin fikirlerin öne sürülmesine neden olmuștur ${ }^{[10]}$. ACE2 enziminin farkl dokulardaki dağılımının hastalarda gözlenen coklu organ yetmezliğini açıklayabileceği de belirtilmiştir ${ }^{[10,12]}$. Diğer bir yapısal viral protein olan $M$ proteini, içerdiği üc farklı transmembran bölgesiyle virionun sekillenmesini, virüs hücre membranının kavislenmesini sağlar ve nükleokapside bağlanır. E proteini virüsün paketlenmesi ve salınması ile viral patogenezde rol oynamaktadır. $\mathrm{N}$ proteini ise RNA yapısındaki viral genoma bağlanan bölgeler içerir. N proteini nsp3 ("nonstructural protein 3": yapısal olmayan protein 3) ile bağlanarak genomun replikasyon-transkripsiyon kompleksine bağlanmasını ve enkapside genomun virion içinde paketlenmesini sağlamaktadır ${ }^{[4]}$.

\section{EPIDEMIYOLOJi}

Etkenin kaynağı henüz kesin olarak tanımlanamamıs olmakla birlikte, ilk olgular epidemiyolojik olarak Wuhan'daki bir canl hayvan ve deniz ürünleri pazarı olan Huanan Deniz Ürünleri Toptan Satıș Pazarı ile ilișkilendirilmiștir. Hastalığın yarasalardan insanlara bulaștığı yönünde öngörüler olduğu gibi, yarasa ile insanlar arasında bir ara konağın bulunduğu, bu ara konağın karıncayiyen (pangolin) olduğu ve yarasa ile pangolin koronavirüslerinin rekombinasyonu ile yeni koronavirüsün ortaya çkmıș olabileceği yönünde görüșler de ileri sürülmüștür ${ }^{[8,10]}$. Hastalığın zoonotik kaynakl olduğu kabul edilmekle birlikte, insandan insana bulaș varlığı da gösterilmiș ve temel bulaș yolu haline gelmiș, kısa süre içinde olgu sayılarında belirgin artış ortaya cıkmış ve hastalı küresel yayılım göstermiștir ${ }^{[5,13,14]}$. Hastalı̆̆ın ortaya çıkıșı sonrasındaki yaklașık olarak ilk iki aylık dönemde en yüksek hastalık ve ölüm oranları Cin'den bildirilmekte iken Mart 2020'nin ilk haftasından itibaren Çin'deki olgu ve ölüm sayıları azalmıs, ancak
Antarktika haric üzerinde insan yașamının bulunduğu tüm kıtalarda hastalık ve ölüm sayıları artmıștır. DSÖ 11 Mart 2020 tarihinde COVID-19'u küresel bir pandemi olarak ilan etmiștir ${ }^{[1]}$.

$\mathrm{Bu}$ derlemenin yayına hazırlandığı 6 Mayıs 2020 tarihindeki verilere göre, 215 farklı ülke ve bölgeden toplam 3.588.773 olgu bildirimi yapılmıs ve hastalığa bağlı 247.503 ölüm rapor edilmistir $^{[15]}$. Ülkemizdeki ilk olgu 10 Mart 2020 tarihinde saptanmıs, hastalığa bağlı ilk ölüm ise 17 Mart 2020 tarihinde bildirilmiștir. Ülkemizde 6 Mayıs 2020 tarihine kadar saptanmıs olan toplam olgu sayısının 131.744, hastalığa bağlı ölüm sayısının da 3584 olduğu belirtilmiștir[16].

Etkenin alınmasından hastalık belirtilerinin ortaya çkmasına kadar geçen sürenin 1-14 gün arasında değișmekte olduğu kabul edilmektedir, ancak bazı olgu raporlarında inkübasyon süresinin daha uzun olduğuna ilișkin bildirimler de mevcuttur ${ }^{[8,17]}$. Bununla birlikte, DSÖ, Amerika Birleșik Devletleri'ndeki Hastalık Kontrol ve Önleme Merkezi [Centers for Disease Control and Prevention (CDC)], Avrupa Hastalık Önleme ve Kontrol Merkezi [European Centre for Disease Prevention and Control (ECDC)] ve ülkemizde Sağlık Bakanlığı Halk Sağlığı Genel Müdürlüğü tarafından temaslıların izlenmesi, karantinada tutulması ve gözlenmesi açısından önerilen süre 14 gündür $^{[1,3,18,19]}$. Etkenin infekte bir kisiden duyarlı kișiye bulaș yolunun solunum sekresyonları olduğu kabul edilmektedir. İnfekte kișinin çlkardığı infeksiyöz damlacıklara doğrudan maruz kalınması veya kontamine olmus deri ve yüzeylerle temas sonrası duyarlı kișinin ağız, burun ve göz mukozasına dolaylı olarak etkeni tașıması yoluyla bulas ortaya cıkabilmektedir ${ }^{[3,8,20]}$. Bulas yolu konusunda, özellikle damlackk ve hava yolu ile bulaș üzerinde devam etmekte olan tartışmalar ve teredduitler nedeniyle, damlack izolasyonu ile solunum izolasyonu (solunum yolu) önlemlerinin hangi durumlarda uygulanması gerektiği konusunda ülkeler veya merkezler arasında farklılıklar gözlenebilmektedir ${ }^{[20]}$. Solunum yolu önlemlerinin özellikle aerosolizasyona neden olabilecek ișlemler gibi solunum sekresyonları ile yoğun temas gerektiren proseduirler sirasında alınması önerilmektedir ${ }^{[3,20]}$. Infekte kișinin bulaștırıcılık süresi ve etkenin diș ortam kosullarındaki dayanıklılık süresine ilișkin bilgiler 
henüz net olarak ortaya konulmamıstır ${ }^{[3,8,19]}$. Bulaștırıcılığın semptomatik dönemden 1-2 gün önce bașlayıp semptomların kaybolmasıyla sona erdiği düșünülmekle birlikte, hastalığın ağırlığına göre viral yayılımın daha uzun sürebildiğine ilișkin görüșler de mevcuttur ${ }^{[3,20]}$. SARS-CoV-2'nin diș ortama dayanma süresi ile ilgili kesinlesmiș bilgi mevcut değildir. Bu sürenin, infekte kișiden dișarı atılan organik madde ve inokülum miktarına; ortamın nemine ve sicaklığına; kontamine yüzeyin yapısı ve dokusu gibi faktörlere göre değișebildiği belirtilmektedir. Cansız yüzeylere temas ile bulașta etkenin dıs ortamdaki aktivitesinin yanı sıra temas süresi de önem tașimaktadır ${ }^{[3,20]}$. Asemptomatik kișilerden veya henüz inkübasyon periyodunda olanlardan da bulaș olabildiği bildirilmiș olmakla birlikte, bu durumun hangi sıklıkta ortaya ç1ktığ1 tam olarak bilinmemektedir ${ }^{[17,20,21]}$. Geniș ölçekli serolojik taramaların asemptomatik infeksiyonun yaygınlığı konusunda daha ayrıntılı bilgi edinilmesine ve epidemiyolojik analizlerin yapilmasına katkı sağlayabileceği belirtilmektedir ${ }^{[20]}$.

Etkenin kan ve dıșkıda da saptanabilmis olması farklı bulaş yollarının da olabileceğini düsündürmüștür ${ }^{[8,22]}$. Farklı bir bulas yolunun varlığının doğrulanması durumunda mevcut izolasyon önerilerine ek önlemler alınması gerekebilecektir, ancak mevcut bilgi ve verilere dayanilarak etkenin damlacık yoluyla bulaștığı kabul edilmekte$\operatorname{dir}^{[2,3,8,23]}$. Sağlık hizmeti ilișkili bulaș da kișiden kișiye infeksiyon yayılımında önemli bir yol oluşturabilmektedir ${ }^{[8,24]}$

Temel coğalma sayısı $\left(\mathrm{R}_{0}\right)$, duyarlı bir popülasyonda, infeksiyonun görüldüğü bir kișinin bulașt1rıcı olduğu dönem boyunca infekte ettiği ortalama kiși sayısı (ikincil olgu sayısı) olarak ifade edilen tahmini değerdir. $\mathrm{R}_{0}<1$ ise infeksiyon zaman içinde azalarak yok olacaktır, $\mathrm{R}_{0}>1$ ise salgın beklenecektir, $R_{0}=1$ ise infeksiyon endemik olarak kalacaktır ${ }^{8,25,26]}$. Bașlangıctaki verilerle, SARS-CoV-2'nin neden olduğu COVID-19 için temel coğalma sayısının 2.24 ile 3.58 arasında olduğu tahmin edilmiș ve SARS'a göre daha yüksek bir pandemik potansiyel öngörülmüștür ${ }^{[5,8,25,27]}$. Kullanılan bir diğer epidemiyolojik tanım olan efektif çoğalma sayısı ise, toplumda hastalığa duyarlı kiși sayısının zaman içinde değișmesiyle farklılașabilen tahmini değerdir. Temel coğalma sayısı ve efektif coğalma sayısı infeksiyonun görüldüğu bir kișinin infekte ettiŏi kiși sayısının tahmini ortalamasını vermektedir. Günümüze kadar yașanmıs salgınların bir kısmında olduğu gibi, bazı kișilerin beklenen ortalamadan daha yüksek sayıda kișiyi infekte edebilmesi de mümkündür. Bu kișiler așırı yayıcı (super spreader) olarak tanımlanır ve onlarca veya yüzlerce kișiye hastalığı yaymaya devam edebilir. Örnek olarak, 2003 yllindaki SARS epidemisinde bașlangıctaki $\mathrm{R}_{0}$ değeri 2.75 civarında hesaplanmıs, birkaç ay içinde efektif coğalma sayısı 1'in altına düssmüs, ancak epidemi devam etmiștir. Bu durumun, özellikle birkac kez yașanmıș olan așırı yayıcılardan kaynaklanan bulașa bağlandığı belirtilmiștir ${ }^{[25]}$.

\section{KLINIK TABLONUN ÖZELLIKLERI}

Pandemi devam etmekte olduğu için, infeksiyon görülen hastalarda yaygın olarak saptanan klinik özelliklerin dağılımı zaman içinde değișim gösterebilmektedir. Yakın zamanda yayınlanmıs bir derlemede, olguların yaklașık olarak \%83-98'inde ates, \%76-82'sinde öksürük, \%11-44'ünde ise kas ağrıları, halsizlik, yorgunluk yakınmalarının gözlendiği, baș ağrısı, boğaz ağrısı, karın ağrısı ve ishalin de klinik tabloya eslik edebildiği belirtilmektedir $^{[8]}$. Anosmi (koku alamama), COVID-19 tanisı konulan hastalarda ayırt edici bir semptom olarak rapor edilmis olmakla birlikte, yayınlanmıs kohort calıșmalarda bu semptom üzerine herhangi bir vurgulama yapılmamıștır ve anosminin görülme sıklığı ile COVID-19'un öngörülmesinde kullanılabilirliği konusunda belirsizlik bulunmakta$\mathrm{d}_{1}{ }^{[20,28]}$. İnfeksiyonun ciddi bulguları arasında en sık görüleni pnömonidir. Hastalığın siddeti ile ilgili tanımlar henüz kesinleșmiș değildir ve farklı gruplandırmalar yapilabilmektedir ${ }^{[3,20,29]}$. Türkiye Cumhuriyeti Sağlık Bakanlığı Halk Sağlığı Genel Müdürlüğü'nün COVID-19 (SARS-CoV-2 İnfeksiyonu) Rehberi'nde, komplike olmamıs hastalı, pnömoni ve ağır pnömoni seklinde sınıflandırılmıştır. Ates, kas/eklem ağrıları, öksürük, boğaz ağr1s1, nazal konjesyon gibi bulguları olup, solunum sıkıntısı, takipne ve $\mathrm{SpO}_{2}<\% 93$ olmayan, altta yatan hastalığı (kardiyovasküler hastalıklar, diabetes mellitus, hipertansiyon, kanser, kronik akciğer hastalıkları bașta olmak üzere diğer immünsüpresif durumlar) bulunmayan, 50 yas altında, akciğer grafisi ve/veya bilgisayarlı tomografisi normal olan 
ve bașvuru sırasında uygulanan kan tetkiklerinde kötü prognostik ölçüt [kan lenfosit sayısı < 800/ $\mu \mathrm{L}$ veya $\mathrm{C}$-reaktif protein $(\mathrm{CRP})>40 \mathrm{mg} / \mathrm{L}$ veya ferritin > $500 \mathrm{ng} / \mathrm{mL}$ veya $\mathrm{D}$-Dimer > $1000 \mathrm{ng} /$ $\mathrm{mL}$ vb.] bulunmayan kișilerdeki klinik tablo komplike olmamıs hastalık olarak değerlendirilmekte; hafif seyirli pnömoni kategorisine solunum sayıs $<30 /$ dakika olup, oda havasında $\mathrm{SpO}_{2}$ düzeyi \%90'ın üzerinde olan, altta yatan hastalığı bulunmayan, 50 yas altında, akciğer grafisinde veya bilgisayarlı tomografisinde hafif pnömoni bulgusu olan, başvuru sırasında uygulanan kan tetkiklerinde kötü prognostik ölçüt bulunmayan hastalar dahil edilmekte; solunum sayısı $\geq 30 /$ dakika olup, oda havasında $\mathrm{SpO}_{2}$ düzeyi \%90'ın altında olan, akciğer grafisinde veya tomografisinde bilateral yaygın pnömoni bulgusu saptanan ve bașvuru sirasında uygulanan kan tetkiklerinde kötü prognostik ölçüt bulunan hastalar ise ağır pnömoni seklinde tanımlanmaktadır ${ }^{[3]}$. Hastalığın siddetinin tanımlanması konusunda yapılan bir diğer sınıflandırmada ise, pnömoni saptanmayan veya hafif pnömoni bulgusu gözlenen hastalar hafif seyirli hastalık; dispne, hipoksi veya görüntülemede 24-48 saat içinde \%50'nin üzerinde akciğer tutulumu saptanan olgular ağır seyirli hastalık; solunum yetmezliği, sok ve çoklu organ yetmezliği gelișen olgular ise kritik hastalık tablosuna dahil edilmektedir ${ }^{[20,29]}$.

Mevcut veriler, ağır pnömoni ve solunum yetmezliği, coklu organ yetmezliği gibi kritik hastalık tablosunda olanların tüm olguların yaklașık olarak \%19-20'sini olușturduğunu göstermektedir ${ }^{[20,29]}$. Akut solunum sıkıntısı sendromu [Acute Respiratory Distress Syndrome (ARDS)], ağır seyirli hastalıkta gelișebilen oldukça önemli bir komplikasyon olarak belirtilmekte, diğer önemli komplikasyonlar arasında aritmi, akut kardiyak hasar, tromboembolik komplikasyonlar ve sok tablosu yer almaktadir $^{[20]}$. COVID-19 seyri sirasında tromboembolik olay gelișiminin patogenezi tam olarak aydinlatılamamıs olmakla birlikte, özellikle vasküler endotel hasarı, vasküler staz gibi hemodinamik değișiklikler ve hiperkoagülabilite üzerinde durulmaktadır. Vasküler endotel hücrelerinin SARS-CoV-2 tarafından direkt invazyonuna, intravasküler kateterlerin kullanımına, akut sistemik inflamatuvar yanit aracıları olan sitokinlere ve diğer akut faz reaktanlarına bağlı olarak veya kompleman aracılı mekanizma ile endotel hasarının gelișebildiği; özellikle hastanede yatan hastalarda ve kritik durumdaki olgularda immobilizasyon nedeniyle kan dolașımında ortaya cıkabilen stazın tromboembolik olaya neden olabildiği; yükselmiș faktör-VIII ve fibrinojen düzeyleri, prokoagülan mikropartiküller, nötrofil hücre diș1 tuzakları gibi dolașımdaki protrombotik faktörlerde ortaya çıan bir dizi değișikliğin ağır COVID-19 olgularında gözlenebildiği ve hiperkoagülabilite durumunu ortaya koyabildiği belirtilmektedir ${ }^{[3,30]}$. Bazı COVID-19 olgularında inatçı ates, D-dimer, ferritin gibi inflamatuvar belirteclerin ve proinflamatuvar sitokinlerin yüksekliği ile seyreden, sitokin salınımı sendromu veya sitokin firtınası olarak tanımlanan duruma benzeyen, așırı veya kontrolsüz inflamatuvar yanita ilișkin bulgular ortaya çkabilmekte, bu laboratuvar bulgularının varlığı kritik hastalıkla ilișkilendirilmektedir ${ }^{[12,20]}$.

SARS-CoV-2 infeksiyonu her yaștaki bireyde görülebilmekte, özellikle orta yaș ve ileri yas grupları daha fazla etkilenmektedir ${ }^{[20]}$. Cocuklarda semptomatik infeksiyonun nadir görüldüğu ve hafif seyirli olduğu belirtilmiș olmakla birlikte, ağır ve komplike olguların varlığı da bildirilmiștir ${ }^{[20,31]}$. Cin ve Güney Kore kaynaklı bazı raporlarda infeksiyon saptanan olguların yaklașık olarak \%2 ile \%6'sı 20 yașın altındaki bireylerdir ${ }^{[29,32]}$. Hastal1ğın hafif seyrettiği olgularda ölüm bildirilmemiștir. Bașlangıcta semptomları hafif olan bazı hastaların kliniğinde bir hafta içinde kötüleșme gözlenebilmektedir. İyileșe süresinin hafif seyirli hastalıkta yaklașık olarak iki haftayı, ağır hastalık tablosunda ise 3-6 haftayı bulabildiği belirtilmektedir ${ }^{[20]}$. Baslangıc semptomlarını takip eden 5-10 gün içinde Guillain-Barre sendromu gelișen olguların varlığına ilișkin bildirimler de bulunmaktadır ${ }^{[20,33]}$.

\section{LABORATUVAR BULGULARI}

COVID-19 olgularında tam kan sayımı bulguları değișkenlik gösterebilmektedir. Olguların çoğunda lenfopeni saptanırken, değișen oranlarda lökopeni veya lökositoz görülebilmektedir. Biyokimyasal incelemede, genellikle laktat dehidrogenaz (LDH) ve ferritin düzeylerinin yüksek olduğu, aminotransferaz değerlerinin de artmıs olarak saptanabildiği belirtilmektedir. Bașvuru sırasında pnömoni saptanan olguların çoğunda serum prokalsitonin düzeylerinin normal sınırlarda olduğu, yoğun bakım gereksinimi olanlarda ise yuikselmis 
olarak bulunabileceği bildirilmiștir. Yüksek D-dimer düzeyleri ve derin lenfopeni varlığı mortalite ile ilișkilendirilmiștir ${ }^{[8,20,34]}$. Türkiye Cumhuriyeti Sağlık Bakanlığı Halk Sağlığı Genel Müdürlüğü'nün COVID-19 (SARS-CoV-2 İnfeksiyonu) Rehberi'nde istenebilecek kan tetkikleri olarak tam kan ve lenfosit sayımı, CRP, prokalsitonin, böbrek ve karaciğer parametreleri, kardiyak enzimler, LDH, koaguilasyon parametreleri, D-dimer, ferritin, fibrinojen, arter kan gazı ve laktat dahil edilmiștir ${ }^{[3]}$.

\section{GÖRÜNTÜLEME BULGULARI}

Akciğer tutulumu olan hastalarda bașlica görüntuileme bulguları olarak, akciğer grafisinde genellikle her iki akciğerde yama tarzı infiltrasyonların görüldüğü, akciğerin bilgisayarlı tomografi ile yapılan değerlendirilmesinde ise viral pnömoni ile uyumlu buzlu cam dansitesinde opasifikasyonların ön planda olduğu belirtilmektedir. Olgu serilerine dayanılarak, tomografik bulguların coğunlukla bilateral olduğu, periferik yayılım gösterdiği ve tutulumun özellikle alt loblarda bașladığı yönünde bilgiler öne sürülmektedir. Daha az sıklıkla, plevral kalınlașma, plevral efüzyon ve lenfadenopati gibi bulguların varlığı da bildirilmektedir ${ }^{[8,20]}$. Akciğer tutulumunun hastalık seyri sırasında ilerleyebildiği, bașlangıc semptomlarından sonraki 10-12 gün civarında tutulumun en yüksek düzeye erișebildiği belirtilmektedir ${ }^{[20]}$.

\section{HISTOPATOLOJIK BULGULAR}

Histopatolojik bulgular ile ilgili bilgiler sinırlı olmakla birlikte, otopside SARS ve MERS olgularında gözlenen bulgulara benzer sekilde, akciğer dokusunda hiyalen membran formasyonu, interstisyel mononükleer inflamatuvar hücre infiltrasyonu ve multinükleer dev hücreler görüldüğü belirtilmiștir ${ }^{[8]}$.

\section{OLGU-FATALITE HIZI}

Olgu-fatalite hızı ülkelere göre değișkenlik göstermektedir. Kardiyovasküler hastalık, diabetes mellitus, konik akciğer hastalığı, hipertansiyon ve kanser gibi eșlik eden hastalığı olup solunum semptomları ağır olan erișkinlerde olgu-fatalite hızı yüksektir. Cin'in Hubei eyaletinden gelen ilk raporlar, özellikle ileri yaștakilerde gözlenen olgu-fatalite hızının, tüm kohortta \%2.3 olarak saptanan olgu-fatalite hızına göre daha yüksek olduğunu, 70-79 yas aralığında bu ölçütün \%8, 80 yaș ve üzerindekilerde ise \%14.8 olduğunu göstermektedir ${ }^{[20,29]}$. Hastalığın diğer ülkelere yayılmasının ardından elde edilen güncel verilere göre global olgu-fatalite hızı yaklașık \%7 olarak değerlendirilmektedir. Olgu-fatalite hız, belirli bir toplumda belirli bir süre içinde belirli bir hastalıktan ölenlerin sayısının aynı süre içinde aynı hastalığa yakalanmıs olanların sayısına oranıdır. Olgu-fatalite h1zının doğru olarak belirlenebilmesi hastalık tablosu hafif olanların da saptanmıș olmasına bağlıdır. Bu nedenle, veriler dikkatle yorumlanmalıdır ${ }^{[15,20,29]}$.

\section{TANISAL TESTLER ve TARAMA}

SARS-CoV-2 açısından tarama yapılması gereken kișiler ve tanısal testlerin hangi kișilere uygulanacağına ilișkin karar ulusal ve yerel sağlık politikalarına göre değișebilmektedir. Ayrıca, bu konudaki kararlar ülke dağılımlarında ortaya c1kan değișikliklere göre de güncellenmektedir. Ülkemizde bu alandaki uygulamaya ilișkin önerilere Türkiye Cumhuriyeti Sağlık Bakanlığı Halk Sağlığı Genel Müdürlüğü'nün https://hsgm.saglik.gov.tr/ tr/covid19 adresindeki "Rehber" ve "Algoritmalar" bașlıkları aracılı̆̆ıla ulașlabilmekte, COVID-19 (SARS-CoV-2 İnfeksiyonu) Rehberi, sağlık kurulușlarında olgu yönetimi akıș seması ve COVID-19 erișkin hasta yönetimi ve tedavisi akı̣ șeması ile ilgili dokümanlara erișilebilmektedir ${ }^{[3]}$.

Tanıda kullanılması önerilen yöntem olan "reverse-transcriptase polymerase chain reaction (RT-PCR)" için primerler, problar ve protokoller CDC tarafından tanımlanmıștır ${ }^{[35]}$. Ülkelerin tanı testlerini hangi merkezlerde uygulayacağına ilișkin kararlar ulusal sağlık otoriteleri tarafından belirlenmektedir. Tanı amacıyla, uygun bölgeden, yeterli miktarda örnek alınması ve alınan örneklerin testlerin uygulanacağı laboratuvara uygun kosullarda ve önerilen süre içinde ulaștırılması gerekmektedir. $\mathrm{Bu}$ amaçla, tanısal testlerin yapilacağı laboratuvarın önerdiği örnek alma ve laboratuvara gönderme prosedürüne titizlikle uyulmalıdır. CDC tarafından, tanı amacıyla üst solunum yolundan alınacak örneğin nazofarengeal sürüntü olması; balgam, trakeal aspirat veya bronkoalveoler lavaj gibi alt solunum yolu örneklerinin gönderilmesi tercih edilmektedir ${ }^{[36]}$. Türkiye Cumhuriyeti Sağlık Bakanl1ğı Halk Sağlığı Genel Müdürlüğü'nün 14 Nisan 2020 tarihli COVID-19 (SARS-CoV-2 İnfeksiyonu) 
Rehberi'nde ise, alt solunum yollarından alınacak örnekler için trakeal aspirat veya bronkoskopik örneklerin tercih edilmesi, alt solunum yollarından örnek alınamadığı durumlarda veya alt solunum yolu semptomları olmayan olgularda nazofarengeal yıkama örneği veya nazal ve/veya orofarengeal sürüntünün birlikte gönderilmesi, ideal olarak önce orofarengeal sürüntünün alınması, sonrasında aynı eküvyon kullanılarak nazal örnek alınması ve aynı tașıma besiyerine konulması önerilmektedir ${ }^{[3]}$.

Tarama ve tanı amaciyla uygulanabilecek, antijen veya antikor saptanması temeline dayanan hızlı tanı testleri de geliștirilmektedir. Hızlı tanı testlerinin uygulanması durumunda, sonucun testin performans ölçütlerine göre yorumlanması gerekmektedir ${ }^{[8,20]}$.

SARS-CoV-2 infeksiyonunun tanıs1, infeksiyon kontrol önlemlerinin alınması ve hasta ile temastakilerin izlenmesi ve taranmasına iliskin uygulamaların yönlendirilmesinde de önem tașımaktadır. Ancak, infeksiyon tanisı amaciyla testlerin istenmis olması, klinik ve epidemiyolojik olarak SARSCoV-2 infeksiyonu süphesi varlığında, infeksiyon kontrol önlemlerinin alınmasını geciktirmemelidir.

Hastalarda, SARS-CoV-2 infeksiyonuna, diğer solunum yolu virüslerinin veya bakteriyel patojenlerin etken olduğu infeksiyonlar eșlik edebilir. Bu nedenle, diğer patojenlere yönelik tanı ve/veya tedavi gereksinimi açısından da hastaların değerlendirilmesi gerektiği unutulmamalıdır.

\section{TEDAVi}

Yeni ajanların ve farklı endikasyonlarda kullanılmakta olup etkinliği araștırılmakta olan ilaçların denenmekte olduğu cok sayıda klinik calıșma devam etmektedir ${ }^{[8,37,38]}$. Viral RNA sentezini inhibe ederek SARS-CoV-2'ye karss in vitro etkinlik gösterdiği bildirilen bir nükleotid analog olan remdesivir "Food and Drug Administration (FDA)" tarafından hastanede izlenen, klinik tablosu ağır [oda havasında $\mathrm{SpO}_{2} \leq \% 94$ olan, oksijen desteği, mekanik ventilasyon veya ekstrakorporeal membran oksijenasyonu (extracorporeal membrane oxygenation; ECMO) gerektiren] eriskin ve cocuk hastalarda intravenöz infüzyon yoluyla kullanılmak üzere acil kullanım izni (emergency use authorization) almıștır ${ }^{[37,39,40]}$. Bununla birlikte, alanin aminotransferaz (ALT) değerinin, normal değerin üst sınırının bes katı ve üzerinde olduğu hastalarda önerilmemekte, tedavi sırasında ALT değerinin belirtilen değerlere yükselmesi durumunda veya karaciğer hasarına ilișkin bulguların varlığında kesilmesi gerektiği belirtilmektedir. Böbrek yetmezliği durumunda remdesivirin farmakokinetiği net olarak bilinmemektedir. Remdesivir, çözünürlüğü arttırıcı bir madde olan siklodekstrin ("sulfobutylether $\beta$-cyclodextrin sodium") içermekte ve böbrek yetmezliği durumunda siklodekstrinin birikerek toksik etkilere neden olabileceği belirtilmektedir. Bu nedenle, potansiyel yararı, potansiyel zararından daha fazla olmadıkça tahmini glomerüler filtrasyon hız1 $30 \mathrm{~mL} / \mathrm{dak} / 1.73 \mathrm{~m}^{2}$ altında olan hastalarda kullanılması önerilmemektedir ${ }^{[37]}$.

Daha önce SARS-CoV'a karșı viral hücre kültüründe etkin olduğu belirtilen klorokin ve hidroksiklorokin de SARS-CoV-2 için denenmis ajanlar arasındadır, ancak tedavi etkinliği konusunda yeterli veri bulunmamaktadır ${ }^{[37,39,41]}$. Bununla birlikte, COVID-19 nedeniyle hastanede izlenen, yürütülmekte olan klinik calıșmalara katılma olanağı bulunmayan erișkin ve cocuk hastalarda kullanılmak üzere FDA tarafından hidroksiklorokin sülfat veya klorokin fosfat için acil kullanım izni verilmiștir $^{[37,42]}$. Hidroksiklorokin veya klorokin bașlanması planlanan veya bu ajanları almakta olan COVID-19 olgularında, özellikle kardiyak yan etki riskinin değerlendirilmesi ve takibinin yapılması, QT aralığını uzatma ve ventriküler tașikardiye yol açma potansiyelleri nedeniyle bazal düzeltilmiș QT aralığı uzun olan veya kardiyak iletim üzerine etkin ilaç kullanmakta olan hastalarda kullanımdan kaçınılması, gerektiğinde kardiyoloji bölüm desteğinin alınması önerilmektedir ${ }^{[3,37]}$. COVID-19 olgularında hidroksiklorokine ek olarak azitromisin kullanılmasının tedavide ek katkı sağladığı da bildirilmiștir, ancak calıșmanın yöntemi ve örneklem büyüklüğü ile ilgili tartıșmalar ve kombine kullanımda kardiyak yan etkilerde artıs olabileceği yönünde cekinceler mevcuttur ${ }^{[37,43]}$. İnsan immünyetmezlik virüsü (HIV) infeksiyonunun tedavisinde kullanılan bir proteaz inhibitörü olan lopinavir/ritonavir de MERS-CoV hayvan modellerindeki etkinliğine dayanılarak COVID-19 tedavisinde denenmiștir, ancak etkinliğinin minimal olduğu veya etkinlik göstermediği yönünde yorumlar bulunmaktadır ${ }^{[37]}$. DSÖ, remdesivir, klo- 
rokin ve hidroksiklorokin ile lopinavir/ritonavirin interferon-beta ile birlikte veya interferon-beta verilmeksizin etkinliğinin değerlendirileceği cok uluslu bir calıșma bașlatmıștır ${ }^{[37,44]}$. Japonya'da influenza tedavisinde kullanilmakta olan RNA polimeraz inhibitörü favipiravir de COVID-19'un deneysel tedavisinde kullanılmak üzere Cin'de onay almıs, ülkemizdeki tedavi protokollerinde de kullanılmaya bașlanmıștır $^{[3,37]}$. Ayrıca, farklı ülkelerde etkinliğinin değerlendirilmekte olduğu klinik calıșmalar da planlanmıștır ${ }^{[38]}$. Tosilizumab, interlökin-6 (IL-6)'nın, reseptörü olan IL-6R'ye bağlanmasını kompetitif olarak inhibe ederek etki gösteren ve bazı romatolojik hastalıkların tedavisinde kullanılan bir monoklonal antikordur. Tosilizumabın IL-6 düzeyi yükselmiș ağır seyirli COVID-19 olgularında etkinliğinin değerlendirilmekte olduğu, IL-6 yolağını hedefleyen diğer ajanlar olan siltuksimab ve sarilumabın da etkinliğinin araștırıldığı klinik calıșmalar bulunmaktadır ${ }^{[37,38]}$. Illgilenilmekte olan diğer seçenekler arasında interferon-beta, hiperimmünglobulin ve konvalesan serumların kullanılması da vardır, ancak bu konulardaki veriler henüz sinirlidir ${ }^{[37,45]}$.

Hastalığın seyri sırasında, özellikle koagülopati yönetimi bașta olmak üzere, uygulanacak destek tedavisi ve komplikasyonlara yönelik yaklașımlar kritik öneme sahiptir. Ülkemizdeki olgu yönetimi semaları güncel veriler, kanıtlar, öneriler ve uzman görüşleri doğrultusunda yenilenmekte, tedavi amacıyla önerilen ilaçlar, dozları, endikasyonları ve destek tedavisi yaklassımları Türkiye Cumhuriyeti Sağlık Bakanlığı Halk Sağlığı Genel Müdürlüğü'nün https://hsgm.saglik.gov.tr/tr/covid19 adresindeki "Rehber" ve "Algoritmalar" bașlıkları altında erisime sunulmaktadır. COVID-19'un tedavisi konusundaki yeni gelișmeler ve sonuçar1 doğrultusunda bu önerilerin güncellenebileceği unutulmamalı, ilgili kaynaktan takip edilmelidir. Yoğun bakım ünitesinde izlem gereksinimi olan hastalarda tedavinin en önemli bileșenlerinden biri hastanın klinik durumuna uygun yoğun bakım desteğinin sağlanmasıdır ${ }^{[3]}$.

\section{KORUNMA ve KONTROL ÖNLEMLERI}

SARS-CoV-2'ye karșı geliștirilmiş ve klinik kullanım için onay almıs bir așı henüz mevcut değildir, ancak așı geliștirme alanındaki çalıșmalar devam etmektedir. Korunma ve infeksiyon kontro- lüne yönelik uygulamalar hastalığın hem toplumda hem de sağlık hizmeti sunumu sırasında yayılımının önlenmesinde büyük önem tassımaktadır. Bu amaçla, kesin veya olası COVID-19 infeksiyonu olan bir kiși ile damlacık infeksiyonuna yönelik korunma önlemleri alınmadan yakın temas etmis olan kișilere yönelik yapılması gerekenler; sağlık tesisinde hastalığın yayılımını/gecisini engellemek üzere alınması gereken infeksiyondan korunma ve kontrol önlemleri; sağlık hizmeti sunumu sırasında sağlık personelinin uygun kișisel koruyucu ekipman kullanım önerileri; hasta odasının özellikleri; hastada kullanılacak tıbbi malzeme ve cihazlara özgü infeksiyon kontrol önlemleri; hasta odasına giris, hastaya yaklașım ve hasta odasından çııs sırasında alınması gereken önlemler; hastanın tetkik veya bașka bir amaçla transportu sırasında uygulanması gerekenler; hastanın cevresi ile hasta c1kartıları ve sekresyonlarıla kontamine yüzeylerin temizliği; hasta odadan cıktıktan sonra bir sonraki hastanın alınmasından önce oda temizliği; ambulans ile hasta nakli; evde hasta ve temaslı izlemi; morg ve defin hizmetlerine yönelik alınacak tedbir ve önlemler; hava yolu, karayolu ve demiryolu ile cenaze nakilleri ile ilgili uyulması gereken kurallar güncel bilgiler doğrultusunda Türkiye Cumhuriyeti Sağlık Bakanlığı Halk Sağlığı Genel Müdürlüğünün COVID-19 (SARS-CoV-2 İnfeksiyonu) Rehberi'nde ayrıntılı bir sekilde açıklanmaktadır ${ }^{[3]}$.

Sağlık calıșanlarının hizmet sunumu sırasında infeksiyona maruz kalması önemli bir sorun oluşturmaktadır. Hastanın sağlık kurulușunda izlendiği süre boyunca tanımlanmıs izolasyon önlemlerine uyulması ve sağlık çalıșanlarının uygun kișisel koruyucu donanım kullanması konusuna özen gösterilmesi gerekmektedir ${ }^{[3,20,29]}$.

\section{SONUC}

Hizla ilerleyen COVID-19 pandemisi ile mücadele edebilmek amaciyla kisa sürede sonuc veren tanısal testlerin, virüse karș1 etkin tedavilerin, güvenli ve etkinliği yüksek așlların geliștirilmesine gereksinim vardır ${ }^{[8]}$. Bu süreçte, hasta kișilerle temastan kaçınılması, solunum hijyeninin sağlanması, el hijyeni önerilerine uyulması, ellerin ağı, burun ve göz ile temasından sakınılması, toplumda ve hastane ortamında hastalığın yayılımını önlemek ve kișisel korunma önlemlerini alabilmek amacıyla önerilmiș olan yaklașımlar doğrultusunda 
hareket edilmesi uygulanabilecek etkin tedbirler arasında yer almaktadır ${ }^{[1-3]}$

\section{ÇIKAR ÇATIȘMASI}

Yazarlar bu makale ile ilgili herhangi bir çkar catıșması bildirmemișlerdir.

\section{KAYNAKLAR}

1. World Health Organization (WHO). Erişim tarihi: 17 Mart 2020. Available from: https://www.who.int/emergencies/ diseases/novel-coronavirus-2019

2. European Centre for Disease Prevention and Control (ECDC). Erişim tarihi: 17 Mart 2020. Available from: https://www.ecdc.europa.eu/en/factsheet-health-professionals-coronaviruses

3. Türkiye Cumhuriyeti Sağlık Bakanlığı Halk Sağlığı Genel Müdürlüğü. Erişim tarihi: 14 Nisan 2020. Available from: https://hsgm.saglik.gov.tr/tr/covid19

4. Chen $Y$, Liu Q, Guo D. Emerging coronaviruses: genome structure, replication, and pathogenesis. I Med Virol 2020;92:418-23.

5. Rothan HA, Byrareddy SN. The epidemiology and pathogenesis of coronavirus disease (COVID-19) outbreak. J Autoimmun 2020;102433.

6. Lu H, Stratton CW, Tang YW. Outbreak of pneumonia of unknown etiology in Wuhan China: the mystery and the miracle. J Med Virol 2020;92:401-2.

7. International Committee on Taxonomy of Viruses (ICTV) Erişim tarihi: 17 Mart 2020. Available from: https://talk. ictvonline.org/

8. Del Rio C, Malani PN. COVID-19-new insights on a rapidly changing epidemic. JAMA 2020; Feb 28.

9. Fehr AR, Perlman S. Coronaviruses: an overview of their replication and pathogenesis. Methods Mol Biol 2015;1282:1 23.

10. Zhang $H$, Penninger JM, Li Y, Zhong $N$, Slutsky AS. Angiotensin-converting enzyme 2 (ACE2) as a SARS-CoV-2 receptor: molecular mechanisms and potential therapeutic target. Intensive Care Med 2020;46:586-90.

11. Hamming I, Timens $W$, Bulthuis ML, Lely AT, Navis $G$, van Goor $\mathrm{H}$. Tissue distribution of ACE2 protein, the functiona receptor for SARS coronavirus. A first step in understanding SARS pathogenesis. J Pathol 2004;203:631-7.

12. Huang $C$, Wang $Y, L i X$, Ren L, Zhao J, Hu Y, et al. Clinical features of patients infected with 2019 novel coronavirus in Wuhan, China. Lancet 2020;395(10223):497-506.

13. Carlos WG, Dela Cruz CS, Cao B, Pasnick S, Jamil S. Novel Wuhan (2019-nCoV) coronavirus. Am J Respir Crit Care Med 2020;201:P7-P8.

14. Wu P, Hao X, Lau EHY, Wong JY, Leung KSM, Wu JT, et al. Real-time tentative assessment of the epidemiological characteristics of novel coronavirus infections in Wuhan, China, as at 22 January 2020. Euro Surveill 2020;25(3).
15. World Health Organization (WHO). Erişim tarihi: 6 Mayıs 2020. Available from: https://covid1 9.who.int

16. Türkiye Cumhuriyeti Sağlık Bakanlığı. Erişim tarihi: 6 Mayıs 2020. Available from: https://covid19.saglik.gov.tr/

17. Bai Y, Yao L, Wei T, Tian F, Jin DY, Chen L, et al. Presumed asymptomatic carrier transmission of COVID-19. JAMA 2020; Feb 21.

18. Centers for Disease Control and Prevention (CDC). Available from: https://www.cdc.gov/coronavirus/2019-ncov/ php/risk-assessment.html

19. European Centre for Disease Prevention and Control (ECDC). Erişim tarihi: 25 Mart 2020. Available from: https://www.ecdc.europa.eu/en/publications-data/resource-estimation-contact-tracing-quarantine-and-monitoring-activities-covid-19

20. UpToDate. Erişim tarihi: 28 Nisan 2020. Available from: https://www.uptodate.com/contents/coronavirus-disease-2019-covid-19-epidemiology-virology-clinical-features-diagnosis-and-prevention

21. Hu Z, Song $C, X u C$, Jin $G, C$ hen $Y, X u X$, et al. Clinical characteristics of 24 asymptomatic infections with COVID-19 screened among close contacts in Nanjing, China. Sci China Life Sci 2020;Mar 4.

22. Zhang $W, D u R H, L i B$, Zheng $X S$, Yang $X L$, Hu B, et al. Molecular and serological investigation of 2019-nCoV infected patients: implication of multiple shedding routes. Emerg Microbes Infect 2020;9:386-9.

23. European Centre for Disease Prevention and Control (ECDC). Erişim tarihi: 20 Mart 2020. Available from: https://www.ecdc.europa.eu/sites/default/files/documents/ COVID-19-Discharge-criteria.pdf

24. Wang D, Hu B, Hu C, Zhu F, Liu X, Zhang J, et al. Clinical characteristics of 138 hospitalized patients with 2019 novel coronavirus-infected pneumonia in Wuhan, China. JAMA 2020; Feb 7

25. University of Michigan. Michigan Medicine. Erişim tarihi: 22 Mart 2020. Available from: https://labblog.uofmhealth. org/rounds/how-scientists-quantify-intensity-of-an-outbreak-like-covid-19

26. Ergönül Ö. Enfeksiyon hastalıkları epidemiyolojisi. Hastane Enfeksiyonları: Korunma ve Kontrol Sempozyum Dizisi 2008;60:30-41.

27. Zhao S, Lin Q, Ran J, Musa SS, Yang G, Wang W, et al. Preliminary estimation of the basic reproduction number of novel coronavirus (2019-nCoV) in China, from 2019 to 2020: a data-driven analysis in the early phase of the outbreak. Int J Infect Dis 2020;92:214-7.

28. American Academy of Otolaryngology-Head and Neck Surgery. Erişim tarihi: 23 Mart 2020. Available from: https:// www.entnet.org/content/coronavirus-disease-2019-resources

29. Wu Z, McGoogan JM. Characteristics of and important lessons from the coronavirus disease 2019 (COVID-19) outbreak in China: Summary of a report of 72314 cases from the Chinese Center for Disease Control and Prevention. JAMA 2020; Feb 24. 
30. UpToDate. Erişim tarihi: 5 Mayıs 2020. Available from: https://www.uptodate.com/contents/coronavirus-disease-2019-covid-19-hypercoagulability

31. Cui $Y$, Tian $M$, Huang $D$, Wang $X$, Huang $Y$, Fan $L$, et al. A 55-day-old female infant infected with COVID 19: presenting with pneumonia, liver injury, and heart damage. I Infect Dis 2020;Mar 17.

32. Korea Centers for Disease Control and Prevention (KCDC). Erişim tarihi: 14 Mart 2020. Available from: https:// www.cdc.go.kr/board/board.es? mid=a30402000000\&bid $=0030$

33. Toscano G, Palmerini F, Ravaglia S, Ruiz L, Invernizzi P, Cuzzoni MG, et al. Guillain-Barre syndrome associated with SARS-CoV-2. N Engl J Med 2020;Apr 17.

34. Chen N, Zhou M, Dong X, Qu J, Gong F, Han Y, et al. Epidemiological and clinical characteristics of 99 cases of 2019 novel coronavirus pneumonia in Wuhan, China: a descriptive study. Lancet 2020;395:507-13.

35. Centers for Disease Control and Prevention (CDC). Erişim tarihi: 17 Mart 2020. Available from: https://www.cdc. gov/coronavirus/2019-nCoV/lab/index.html

36. Centers for Disease Control and Prevention. Interim Guidelines for Collecting, Handling, and Testing Clinical Specimens from Persons for Coronavirus Disease 2019 (COVID-19). Erişim tarihi: 15 Mart 2020. Available from: https://www. cdc.gov/coronavirus/2019-nCoV/lab/guidelines-clinical-specimens.html

37. UpToDate. Erişim tarihi: 5 Mayıs 2020. Available from: https://www.uptodate.com/contents/coronavirus-disease-2019-covid-19-management-in-hospitalized-adults

38. National Institute of Health Clinical Trials. Erişim tarihi: 28 Nisan 2020. Available from: https://clinicaltrials.gov/ct2/ results? cond $=$ covid -19

39. Wang $M$, Cao R, Zhang L, Yang X, Liu J, Xu M, et al. Remdesivir and chloroquine effectively inhibit the recently emerged novel coronavirus (2019-nCoV) in vitro. Cell Res 2020;30:269.
40. US Food and Drug Administration (US FDA). Remdesivir letter of EUA. Erişim tarihi: 6 Mayıs 2020. Available at: https://www.fda.gov/media/137564/download

41. Keyaerts E, Vijgen L, Maes P, Neyts J, Van Ranst M. In vitro inhibition of severe acute respiratory syndrome coronavirus by chloroquine. Biochem Biophys Res Commun 2004;323:264-8.

42. US Food and Drug Administration (US FDA). Erişim tarihi: 6 Mayıs 2020. Available at: https://www.fda.gov/media/136534/download

43. Gautret $P$, Lagier JC, Parola P, Hoang VT, Meddeb L, Mailhe $M$, et al. Hydroxychloroquine and azithromycin as a treatment of COVID-19: results of an open-label non-randomized clinical trial. Int I Antimicrob Agents 2020;Mar 20:105949.

44. American Association for the Advancement of Science (AAAS). Erişim tarihi: 5 Mayıs 2020. Available at: https:// www.sciencemag.org/news/2020/03/who-launches-global-megatrial-four-most-promising-coronavirus-treatments\#

45. National Institute of Health. Erişim tarihi: 21 Nisan 2020. Available from: https://www.covid19treatmentguidelines. nih.gov/therapeutic-options-under-investigation/

\section{Yazıșma Adresi/Address for Correspondence}

Doc. Dr. Sehnaz ALP

Hacettepe Üniversitesi Tip Fakültesi,

İnfeksiyon Hastalıkları ve

Klinik Mikrobiyoloji Anabilim Dalı,

Ankara-Türkiye

E-posta: alpsehnaz@gmail.com 